\title{
Toxinology in the proteomics era: a review on arachnid venom proteomics
}

\author{
Filipi Calbaizer Marchi ${ }^{1}$, Edneia Mendes-Silva ${ }^{1}$, Lucas Rodrigues-Ribeiro ${ }^{1}$, Lucas Gabriel Bolais-Ramos ${ }^{1}$, \\ Thiago Verano-Braga ${ }^{1 *}$ (D) \\ ${ }^{1}$ Department of Physiology and Biophysics, Institute of Biological Sciences, Federal University of Minas Gerais (UFMG), Belo Horizonte, MG, Brazil.
}

\section{Keywords:}

Proteomics

Scorpions

Spiders

Venomics

\begin{abstract}
The word venomics was coined to acknowledge the studies that use omics to investigate venom proteins and peptides. Venomics has evolved considerably over the last 20 years. The first works on scorpion or spider venomics were published in the early 2000's. Such studies relied on peptide mass fingerprinting (PMF) to characterize venom complexity. After the introduction of new mass spectrometers with higher resolution, sensitivity and mass accuracy, and the next-generation nucleotide sequencing, the complexity of data reported in research on scorpion and spider venomics increased exponentially, which allowed more comprehensive studies. In the present review article, we covered key publications on scorpion venomics and spider venomics, presenting historical grounds and implemented technologies over the last years. The literature presented in this review was selected after searching the PubMed database using the terms "(scorpion venom) AND (proteome)" for scorpion venomics, and "(spider venom) AND (proteome)" for publications on spider venomics. We presented the key aspects related to proteomics in the covered papers including, but not restricted to, the employed proteomic strategy (i.e., PMF, two-dimensional gel electrophoresis, shotgun/bottom-up and/or top-down/ peptidome), and the type of mass spectrometer used. Some conclusions can be drawn from the present study. For example, the scorpion genus Tityus is the most studied concerning venomics, followed by Centruroides; whereas for spiders the studied genera were found more equally distributed. Another interesting conclusion is the lack of high throughput studies on post-translational modifications (PTMs) of scorpion and spider proteins. In our opinion, PTMs should be more studied as they can modulate the activity of scorpion and spider toxins.
\end{abstract}

* Correspondence: tvbraga@ufmg.br https://doi.org/10.1590/1678-9199-JVATITD-2021-0034 Received: 29 March 2021; Accepted: 01 June 2021; Published online: 28 February 2022 


\section{Background}

Venomous animals have one or more venom glands, and they usually have a specialized apparatus to inject the venom into their prey or use it for defense. There are examples of marine and terrestrial venomous animals, such as Physalia sp. (phylum Coelenterata) and Tityus sp. (phylum Arthropoda), respectively.

Scorpions and spiders (phylum Arthropoda, subphylum Chelicerate, class Arachnida) have their bodies divided into cephalothorax and abdomen. Scorpions have their venom apparatus located at the last abdomen segment named telson. Scorpions' diet is based on arthropods and small animals, such as gecko (phylum Chordata, class Reptilia). There are 2,200 known scorpion species distributed over 19 families but the most studied one is the Buthidae (Koch, 1837), as it accounts for $95 \%$ of all reported scorpion accidents [1-4].

Buthidae scorpions are separated into two geographical groups. The Old-World scorpions are found mainly in Northern Africa, Southern Europe and the Middle East, while the NewWorld scorpions are distributed in the Americas [5]. Regarding scorpions of medical importance, the Old-World genera are represented by Androctonus (Ehrenberg, 1828), Leiurus (Ehrenberg, 1828), and Buthus (Leach, 1815), among others. The New-World genera include mainly Centruroides (Marx, 1890) and Tityus (Koch, 1836). Specifically, Androctonus sp., Leiurus sp. and Buthus sp. are distributed in the Saharo-Sindian zone, a vast and arid region spanning from northwestern Africa to India; whereas Tityus sp. are mainly distributed in South America and Centruroides sp. are found in Central America and Mexico [3].

In general, scorpion venoms are composed of salts, small molecules, peptides and proteins [e.g., bradykinin-potentiating peptides (BPPs), Nav-neurotoxins (NaTxs), Kv-neurotoxins (KTxs), Cav-neurotoxins (CaTxs), among others] [4-7]. Envenomation by Androctonus sp. are painful and can lead to cardiovascular manifestation as cardiac arrhythmia and ultimately heart failure [4]. Leiurus sp. sting cause local pain, burn and swelling. Systemic manifestations may include cardiovascular impairment (e.g., tachycardia, hypertension or hypotension, etc.), priapism, and vomiting [4].

The Buthus genus was subjected to a major taxonomical update, which reclassified as new species animals that used to be known as $B$. occitamus. Most epidemiological reports have been based on B. occitamus cases in Morocco and based on the current taxonomical classification this species is not found in this country. Therefore, more epidemiological data are required to state the common medical manifestations of accidents with this genus $[4,8]$.

Regarding New-World genera, most common clinical manifestations of Tityus sp. accidents include local pain and burning at sting site. Systemic symptoms may include headache, vomiting, sweating, dizziness, hypersalivation, circulatory failure, cardiac arrythmias and respiratory arrest [4]. Regarding Centruroides sp. stings, the most frequent clinical outcomes include pain, local edema and fever. It can also lead to cardiovascular and respiratory impairments [4].
According to the "World Spider Catalog" (https://wsc.nmbe. ch/), there were 49,173 registered spider species by February $25^{\text {th }}$ 2021 distributed worldwide. Similar to scorpions, spiders use their venom for predation and defense. These arachnids have a pair of venom glands in each chelicera at the cephalothorax. Spiders' diet is based on insects [9] but larger spiders, as Lasiodora sp. (Koch, 1850), can eat small vertebrates as well.

Spider venoms may contain ions; small molecules, such as nucleotides, amines, amino acids, and polyamines; proteins (e.g., phospholipases, metalloproteases); and peptides (e.g., neurotoxins and insecticidal peptides) $[10,11]$. Accidents with spiders are registered in many countries but, interestingly, only four genera account for most severe accidents; Atrax (Pickard-Cambridge, 1877), Loxosceles (Heineken \& Lowe, 1832), Latrodectus (Walckenaer, 1805), and Phoneutria (Perty, 1833) $[12,13]$. Loxosceles sp. (family Sicariidae) and Latrodectus sp. (family Theridiidae) are distributed worldwide, whereas Phoneutria sp. (family Ctenidae) is mainly found in Central and South America, and Atrax sp. (family Atracidae) in Australia.

Loxosceles sp. venom is mainly composed of phospholipases, metalloproteases, hyaluronidases, insecticidal peptides, among others [14]. Accidents can cause local necrosis and hemodynamic alterations, eventually leading to acute renal failure $[15,16]$. Latrodectus sp. venoms are composed of neurotoxic peptides for vertebrates (e.g., $\alpha$-LTX), crustaceans (e.g., $\alpha$-LCT) and insects (e.g., a-LIT) [17]. Widow spider (Latrodectus sp.) bites are painful and may lead to systemic manifestations, including nausea, headache, fatigue and ultimately injuries in the cardiac tissue [18]. Phoneutria has an aggressive behavior thus, accidents are not rare. A number of neurotoxins ( 40 molecules as reported by [19]) from $P$. nigriventer venom has already been identified $[19,20]$. Phoneutria sp. envenomation causes local pain. It can also cause priapism and systemic envenomation, though it rarely leads to death $[21,22]$. Atrax robustus, the Sydney funnelweb spider, is a notorious species from the Atrax genus as it is acknowledged as the deadliest spider worldwide [18], mainly due to its Nav neurotoxins named $\delta$-hexatoxins ( $\delta$-HXTXs) [23]. Atrax envenomation is painful and may lead to severe systemic and life-threatening effects, related with autonomic and neuromuscular excitation [18].

Even though spiders and scorpions cause health problems, there is a brighter side associated with them as scientists learnt over time that venom peptides are also associated with beneficial outcomes. Examples are: the anti-hypertensive peptide family in Tityus sp. venoms, named hypotensins [24-26]; a cryptic peptide from the hypotensin I (Ts14) is a potential cardioprotective agent [27]; the PnTx2-6 toxin from Phoneutria nigriventer venom that causes priapism [28] was latter redesigned in laboratory as a nontoxic peptide with potential application as an erectile dysfunction treatment [29]; anti-thrombotic and anti-inflammatory peptides $[30,31]$, antimicrobial peptides $[32,33]$, and bio-insecticides [34], etc.

The molecular diversity of scorpion and spider venoms are frequently acknowledged as "treasure chests" [35]. Several 
approaches are used to access the molecular diversity hidden inside venoms but the most popular one is probably the mass spectrometry-based proteomics. In this review we aimed at presenting key publications in venom proteomics, often referred to as venomics, in the context of scorpions and spiders, as well as recent advances in the field. We will also present recent advances in bioinformatics and proteomics that can assist in studying the proteome of scorpion and spider venoms.

\section{Proteomics and its use in toxinology}

Venom composition of many arachnid species has remained undefined for a long time due to limitations of traditional biochemical approaches to analyze small amounts of venoms that are usually extracted from spiders and scorpions [36]. Early studies to characterize scorpion venom components consisted in extensive chromatographic steps to isolate them and subsequent evaluation of their biological activity and potential three-dimensional structures [37], in a "function-to-structure" approach. However, progress in the omics field (genomics, transcriptomics and proteomics) allowed high throughput characterization of venom composition, and discovery of new peptides and proteins [38], in a "structure-to-function" approach.

Venomics has emerged by the use of proteomics to study venom composition. It can also refer to a broader omics (proteome, genome, transcriptome, metabolome) venom characterization [39], but in this review we will focus on venom proteomics. Although one of the firsts high throughput studies of an arachnid venom proteome was reported in the early 2000's [40], mass spectrometry (MS)-based analysis was first used in 1979 to characterize venom metabolites from the Sydney funnel-web spider Atrax robustus by gas chromatography-mass spectrometry (GCMS) [41]. However, it was more difficult to use MS to study peptides and proteins before the 1980's due to the lack of soft ionization techniques [42]. This problem was solved when the electrospray ionization (ESI) was invented by John Bennett Fenn in 1984 [43] and the matrix-assisted laser desorption/ ionization (MALDI) was invented by Franz Hillenkamp and Michael Karas in 1985 [44].

Venomics has evolved substantially over the last 20 years. It is frequently employed to study arachnid venoms these days as seen by the exponential increment of publications using venomics (Figure 1). However, there are limitations on its use to study arachnid venoms as, not rarely, the genome or venom gland transcriptome of a given specie has not been sequenced. A way to circumvent this problem is by sequencing de novo venom peptides, either by manual interpretation of MS/MS spectra or assisted by algorithms that allow high throughput de novo peptide sequencing [45]. On this regard, Gorshkov et al. [46] published an algorithm to assist peptide de novo sequencing.

Different proteomic approaches allow characterizing venom compositions. There are many venomic workflows that can be employed but general workflows for top-down and shotgun/ bottom-up are presented in Figure 2. Since arachnid proteomes are also subjected to post-translational modifications (PTMs), we included PTMs enrichment steps in the provided workflow (Figure 2) as we believe PTMs should be studied more in arachnid venoms. Importantly, detail protocols to study PTMs in general have been published $[47,48]$ and can be employed in the venomic context as well.

\section{Bioinformatics in the context of arachnid venomic studies}

UniProt, NCBI Genbank/GenPept, and the Protein Data Bank (PDB) provide large datasets, playing essential roles in providing access to information regarding protein sequences, threedimensional structures (if available) and biological activity.

Throughout the years, attempts have been made to create new databases with more specific information on venom proteins and toxins. The International Venom and Toxin Database, the Tox-Prot program, the snake neurotoxin database, the scorpion toxin database, and the Animal Toxin Database (ATDB) were created to supply an early need to merge information about venom proteins [49]. However, most of them are based on unformatted text, restricted taxonomic groups, and lack of system effectiveness for data mining, resulting in discontinuing of the service or being incorporated by other databases $[39,49]$. On the other side, within UniProt, for example, the UniProtKB/ Swiss-Prot Tox-Prot program, based on the Tox-Prot program, can provide access to venom protein sequences and functions from several venomous species [50]. The animal toxin annotation project, using the Tox-Prot program, aims at systematically annotate proteins secreted in animal venom, including spiders and scorpions, among other species $[50,51]$. In this respect, the Swiss Institute of Bioinformatics (SIB) developed a free webresource regrouping information from the UniProtKB/Swiss-Prot database (manually annotated and reviewed) and UniProtKB/ Trembl (automatically annotated) on venom proteins, mostly

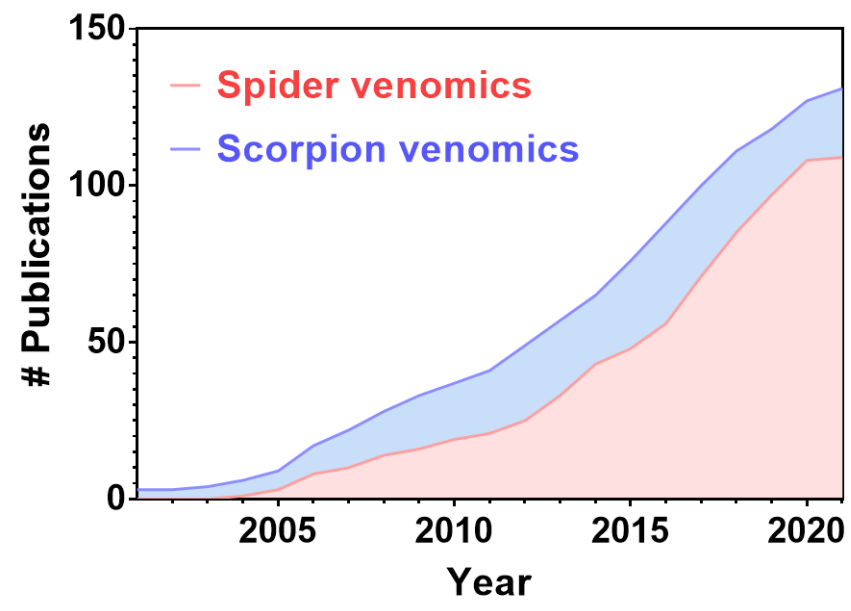

Figure 1. Number of publications on scorpion venomics and spider venomics. Results were retrieved from PubMed (https://pubmed.ncbi.nlm. nih.gov/) by March 2021 using the following search parameters: "(scorpion venom) AND (proteome)" for scorpion venomics or "(spider venom) AND (proteome)" for spider venomics. 


\section{TOP-DOWN VENOMICS}

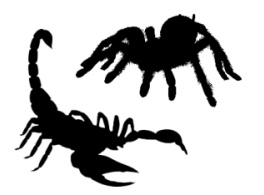

ELECTROSTIMULATION

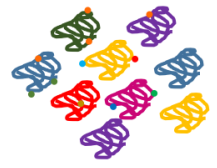

PROTEIN DENATURATION

Reduction disulfide bridges Alkylation thiol groups

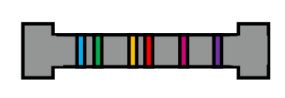

PROTEIN SEPARATION

HPLC/UPLC

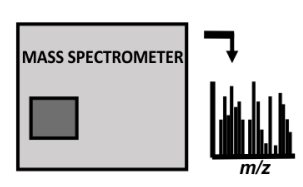

MS ANALYSIS

LC-ESI-MS (ETD / UVPD fragmentation)

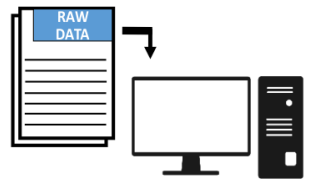

ANALYSIS

PROTEOFORMS

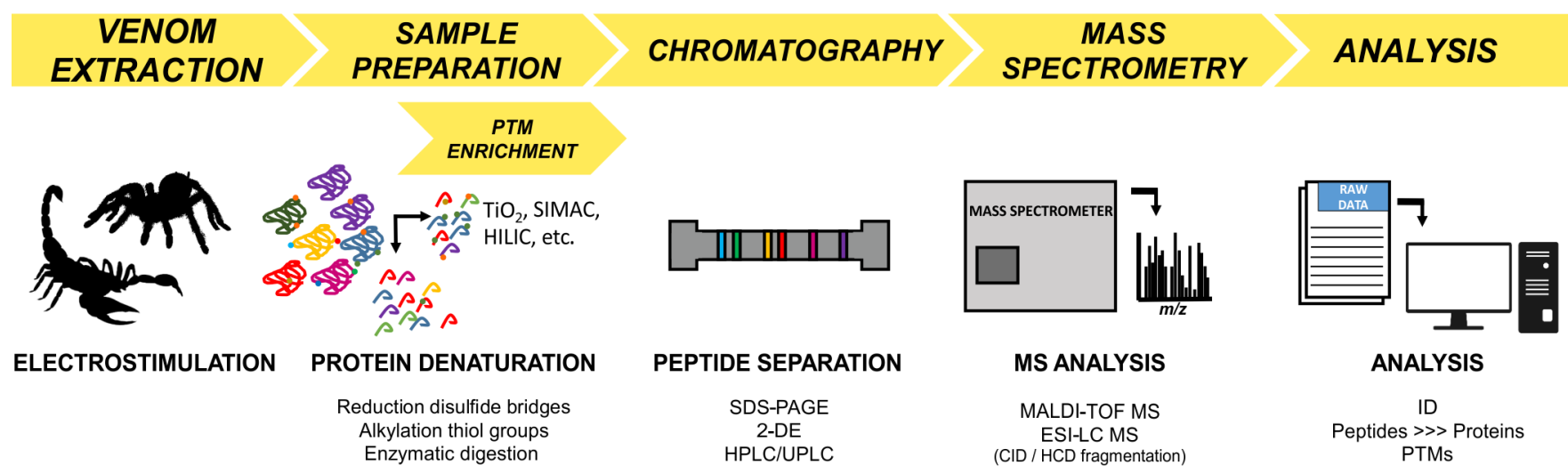

\section{BOTTOM-UP VENOMICS}

Figure 2. Venomic workflow. General workflows for top-down and bottom-up venomics are presented.

with toxic activity. Information access is divided into taxonomy, activity, venom protein families, and PTMs in venom proteins, having data about six taxa, including scorpions and spiders (https://venomzone.expasy.org/).

Although these databases are critical for comparison of toxins across different groups of venomous animals, there is no established standard for practical annotation of information about peptides and proteins from many venom species, especially the names of toxins, the description of the function, and the classification of toxins [51,52]. This lack of consistency leads to numerous duplications of entries and low efficiency for searches. This results in a barrier against data exchange and comparison, making data mining difficult and estimations imprecise. A few attempts on standardization protocols propose the use of machine learning-based classifiers. ToxClassifier is a machine learning web-based tool for the prediction of likely animal toxin sequences, allowing to distinguish toxins from non-toxin sequences. It also increases curation of existing databases by reporting the best-hit annotation and classifying a toxin into the most correct toxin protein family (http://bioserv7.bioinfo.pbf.hr/ ToxClassifier/index.jsp; [53]). In contrast, specialized databases from venomous animals are slowly emerging. These databases are usually a rich information pool of manually curated content that deal with specific subsets of animal toxins [52].
SCORPION, launched in 2002, was a specialized database of scorpion toxins. Its main focus was to facilitate the design of experimental protocols [54]. The structure was designed to provide a basis for extending and clarifying the existing structural and functional classification of scorpion toxins data with easy integration of bioinformatics tools for additional analyses, like identification of sequence patterns associated with specific structural or functional properties of scorpion toxins [54]. An update, SCORPION2, with an increase in the records present in the database was launched a few years later. Combining search algorithms with prediction tools allowed users to extract and perform specific queries: text searches of scorpion toxin records, sequence similarity search, extraction of sequences, visualization of scorpion toxin structures, analysis of toxic activity, and functional annotation of previously uncharacterized scorpion toxins [55].

Another specialized database for scorpion toxins is the Kalium (http://kaliumdb.org/). This database is an open-access resource that collects manually curated data on potassium channel toxins (KTxs) purified from scorpion venom and provides an easy link to general databases such as UniProt, PDB, NCBI Taxonomy Browser, and PubMed.

On the other side, Arachnoserver (http://www.arachnoserver. org/) provided information on venoms from spider species. This manually curated database was centered on mature active 
peptides, containing 1,576 molecules as of October 2020, which were retrieved from UniProtKB. It contained information on the sequence, three-dimensional structure, and biological activity of protein toxins. All mature toxins in ArachnoServer were named according to the standard nomenclature for spider toxins proposed by King in 2008 [56], with the inclusion of alternative names found in the literature to facilitate researches. Its strategy focused on displaying one toxin sequence per entry on a page, providing cross-references to several databases, including the EMBL nucleotide data bank, which allows retrieval of the original nucleotide sequence submission.

In the next couple of sections, we will cite most publications on spider venomics and scorpion venomics. We will also provide a table with key information about the cited publications, as well as an interaction map that connects predefined "terms" (spider or scorpion, genera, use of transcriptomics, proteomic methods, MS platforms, and corresponding author) extracted from the publications (Figure 3).

\section{Spider venomics}

One of the first studies on spider venomics was published in 2005. Machado et al. [57] used a range of proteomic techniques to access the venom proteome of the brown spiders (Loxosceles gaucho, L. intermedia and L. laeta; family Sicariidae), with particular interest in analyzing the dermonecrotic toxin loxnecrogin and its potential proteoforms. Two-dimensional gel electrophoresis (2-DE) showed that the potential loxnecrogin' proteoforms spanned from $p \mathrm{I} \sim 4.4$ to 7.3 and $30-35 \mathrm{kDa}$ mass range. Gel bands corresponding with the potential loxnecrogin' proteoforms were in-gel digested and subjected to peptide mass fingerprinting (PMF) by means of MALDI-TOF MS, and de novo sequenced by Edman degradation and MS/MS (ESI-Q-TOF MS). The authors hypothesized that toxins proteoforms (isoforms) might be related to evolutionary adaptation, maximizing both hunting and defense capabilities. Moreover, they emphasized how the purification and characterization of toxins in venom proteomes are fundamental to understand the physiopathology of envenomation.

Similarly, Richardson et al. [35] compared the partial proteome of spider venoms from the genus Phoneutria (Phoneutria nigriventer, $P$. reidyi and $P$. keyserlingi; family Ctenidae) in 2006. Out of 400 protein and peptide species detected in this study, 100 complete or partial sequences were obtained by Edman degradation and MS/MS (ESI-Q-TOF MS). Two new families of small toxins, some larger protein components, and two serine proteinases from the $P$. nigriventer venom were described. The authors also compared the P. keyserlingi venom proteome from male and female specimens by 2 -DE, reporting a sexual dimorphism.

Yuan et al. [58] reported a venom proteomic and peptidomic study of the Chinese "bird spider" Ornithoctonus huwena (family Theraphosidae). The authors employed gel filtration chromatography to separate peptides $(\mathrm{MW}<10 \mathrm{kDa})$ from proteins $(\mathrm{MW}>10 \mathrm{kDa})$. Venom proteins were separated by 1-DE and 2-DE. After in-gel digestion, proteolytic peptides were analyzed by ESI-Q-TOF MS/MS or MALDI-TOF-TOF MS. Protein identification was done by Mascot search engine. Separation of venom peptides (peptidome) was done by CIEXHPLC followed by RP-HPLC. Peptide sequencing was achieved by MALDI-TOF MS and Edman degradation. 90 proteins (MW > $10 \mathrm{kDa}$ ) were identified using the proteomic approach, including enzymes, binding proteins, and others. Using the peptidomic approach, the authors reported more than 100 components (MW $<10 \mathrm{kDa}$ ) in the $O$. huwena venom, including 47 sequenced peptides. Their findings showed pieces of evidence suggesting gene duplication, focal hypermutation and post-translational modifications (PTMs) in spider toxins as probable origin for the diversity of spider venom proteins and peptides.

Analytical methods evoked in a rapid pace over the last 20 years, including the introduction of the orbitrap mass analyzer [59] and next-generation mRNA and DNA sequencing. Venomics surfed on this innovative wave, boosting the complexity and depth of venom profiling, as seen by more recent publications on spider venomics [58-73], some of which shall be described in next paragraphs.

The study of Oldrati et al. [60] illustrates a rapid and efficient method for the analysis of venom composition based on venom glands mRNA sequencing and venom proteome profiling. Their focus was the analysis of cysteine rich peptide toxins from four different spider species: Heteropoda davidbowie (family Sparassidae), Poecilotheria formosa (family Theraphosidae), Viridasius fasciatus (family Viridasiidae) and Latrodectus mactans (family Theridiidae). This approach led to the profiling of 284 characterized cysteine rich peptides with high resolution, 111 of which were part of the Inhibitor Cysteine Knot (ICK) structural motif. The $H$. davidbowie venom revealed high diversity in venom composition, 32 peptides (of 95 identified peptide) were classified in 6 distinct families containing the ICK structural motif. The $P$. formosa venom accounted for 126 peptide sequences, with 52 ICK toxins being part of 3 distinct families. $V$. fasciatus venom contained 49 peptide sequences, with 22 ICK structural motif peptides from 5 families. The venom of $L$. mactans had 14 cysteine rich peptides, with 5 ICK toxins from 1 family (CSTX superfamily).

The work of Kuhn-Nentwig et al. [61] is quite interesting. Aiming to add new insights into the structure and function of spider venom toxins and their influence on the homeostasis of prey and/or aggressors, a comprehensive analysis of the venom gland transcriptome and proteome from Cupiennius salei (family Trechaleidae) was employed. The venom proteome of C. salei was studied combining bottom-up and top-down proteomics using LC-ESI-Orbitrap MS. Protein and peptide identification was performed using the UniprotKB database supplemented with sequences translated from the venom gland transcriptome. The authors detected 81 transcripts of neurotoxins from 13 peptide families, including 54 putative (based on transcriptome) neurotoxins. Their proteome approach allowed to validate the 


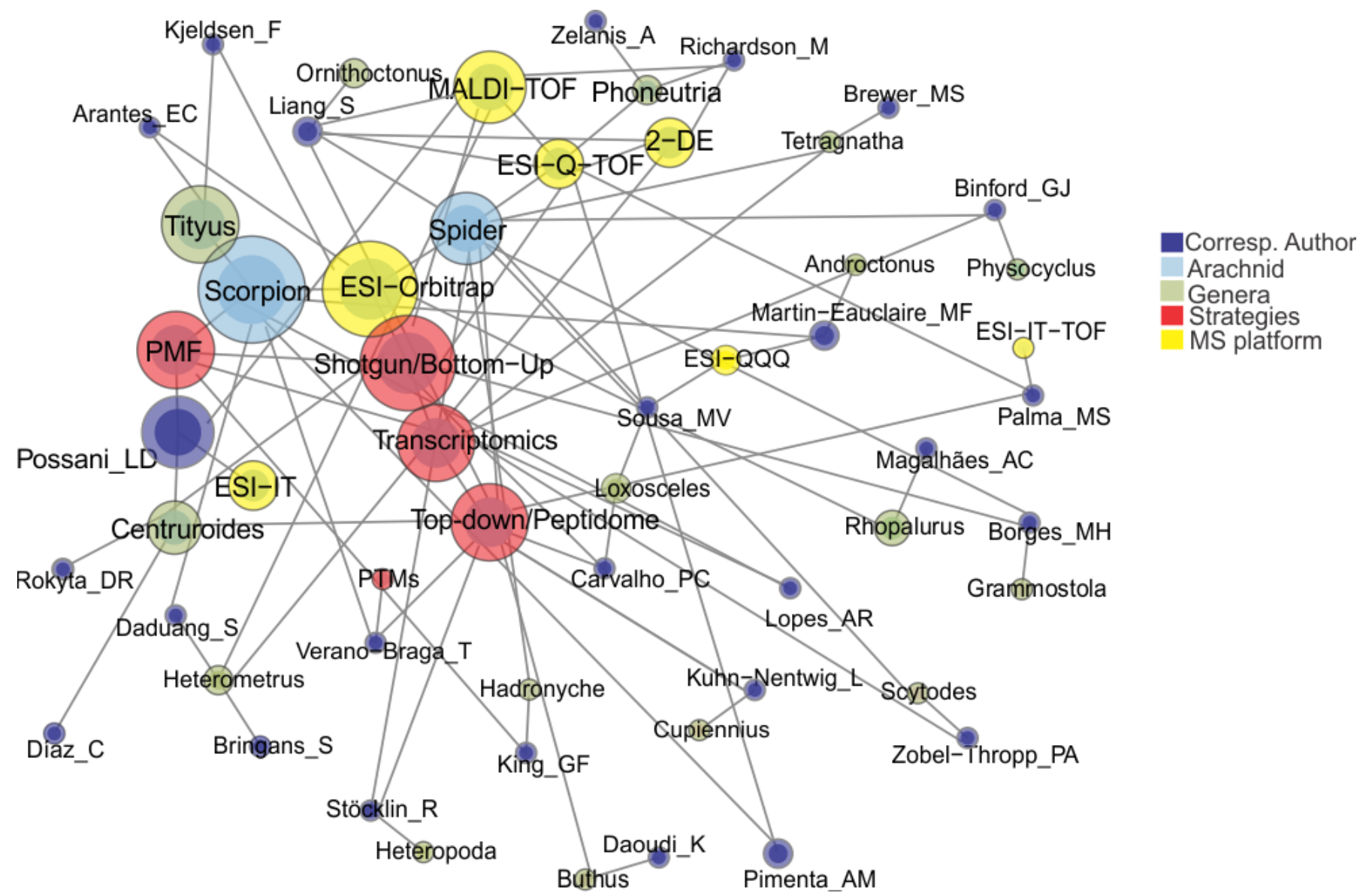

Figure 3. Summary of publications on venomics. Interaction map reporting the main terms (arachnid genera, venomic method, mass spectrometry platform, and corresponding author) found in the publications represented in this review. Node size is associated with the frequency that each term appeared in all publications.

presence of 49 proteins out these putative 54 neurotoxins. Finally, the authors proposed a venom dual-mode of action, in which neurotoxins disable the prey or aggressor while metabolites impair animals' homeostasis.

Diniz et al. [62] were interested in providing a broad screening of the venom proteins produced in the Phoneutria nigriventer venom glands. To accomplish this goal, they combined conventional and next-generation cDNA sequencing with Multidimensional Protein Identification Technology (MudPIT). Transcriptomic and proteomic data showed that cysteine-rich peptide toxins were the most abundant component in the venom. They also reported several potential variants or proteoforms of already described cysteine-rich peptide toxins, and novel ones with unknown function were identified too. The authors concluded that the observed relative abundance of insecticide toxins may have an important role in the envenomation of natural prey.

Santana et al. [63] performed proteomics characterization of ontogenetic variation within a population of Phlogius crassipes (Australian tarantula) to investigate how spider venom composition may be influenced by different predatory niche factors such as sex, diet, habitat, and climate. This study revealed that $P$. crassipes venom changes continuously according to spider size, which could be due to a change in the preys that the spiders encounter at different life stages, mainly due to mating searches, as adult male specimens may incorporate toxins at this life stage that enable them to defend themselves from predators.

Sanggaard et al. [65] used comparative genomics as well as venomics to study the venom and silk proteomes from the African social velvet spider, Stegodyphus mimosarum, and the Brazilian white-knee tarantula, Acanthoscurria geniculata. The analysis of spider venom showed that both spider species contained a large repertoire of cysteine-rich peptides, which most likely mediate the toxic effects of the venom, possibly by processing and activating protoxins. They also found that the dragline silk of the velvet spider is composed by at least two types of spidroins (spider silk proteins). Four novel spidroin-related sequences were identified.

Tang et al. [67] used high throughput peptide identification techniques on the venom of the tarantula Haplopelma hainanum (Ornithoctonus hainana; family Theraphosidae), a highly venomous spider found in southern region of China. The authors employed three different approaches: i) transcriptomics, ii) peptidomics, and iii) genomics. Around 420 peptide toxins were detected by MS, and 272 peptide precursors were deduced from cDNA and genomic DNA sequences. After data processing, 192 mature sequences were identified by combining the three 
omics approaches. Peptide toxins could be classified into 11 superfamilies based on sequence similarity. Additionally, the results suggested a possibly gene duplication and focal hypermutation that could be responsible for the huge molecular diversity observed in spider peptide toxins.

One of the latest reports on spider venomics was published last year in PNAS. The authors employed several omics approaches to study what they called the "structural venomics" of the Australian funnel-web spider Hadronyche infensa (family Atracidae). For venom profile, they used a combination of LC-MS platforms to analyze intact peptides (peptidome) and tryptic digested peptides using the lab-made $H$. infensa venom gland transcriptome for database search (bottom-up proteome approach). Structural determination was done using NMR after expression of identified proteins. The authors detected 3,051 unique peptides in the venom of $H$. infensa. Based on this impressive identification number, they concluded that the $H$. infensa venom peptidome is one of the most complex in terrestrial venomous animals. Their proteome approach allowed the identification of 1,108 venom proteins out of the 1,224 predicted ones by the transcriptome approach. Finally, this work unveiled that the inhibitor cystine knot (ICK) toxins are highly dominant protein structures in the H. infensa venom [68].

\section{Scorpion venomics}

One of the first scorpion venom proteome studies was performed in 2001. Pimenta et al. [40] performed a PMF of the Tityus serrulatus (family Buthidae) venom. The authors employed two MS platforms (online LC-ESI-QQQ MS and offline LC-MALDI-TOF MS) to analyze the toxic fractions of T. serrulatus venom, obtained by Sephadex G50 size exclusion chromatography, reporting over 300 ion species as potential venom toxins.

In 2004, Batista et al. [74] reported that proline-rich peptides from the Tityus cambridgei venom were prone to in-source fragmentation in ESI. The authors also characterized a new Nav toxin by Edman degradation and MS. In the following years, the New-World scorpions were subject to various venomic studies, including an interesting report of individual variability in T. serrulatus venom. Pimenta et al. [75] reported intraspecimen variation in the composition of $T$. serrulatus venom depending on starvation duration. Of course, inter-specimens' variability was also observed [75]. Due to the importance of molecular phenotypes to the understanding of phylogenetic and ecological relations, many other proteomic studies analyzed intraspecific variations in scorpion venom proteins and peptides [76], including sexual dimorphism [77].

In 2006, Nascimento et al. [78] explored more the potential correlation of venom composition and interspecific variations. The authors evaluated whether venomics could be used to assist scorpions' taxonomical classification in Buthidae family. Three species from the New-World (Tityus stigmurus, T. serrulatus, T. bahiensis) and two subspecies from the Old-World (Leiurus quinquestriatus quinquestriatus and L. quinquestriatus hebraeus) were used in this study. The authors used 2D-LC (CIEX and $\mathrm{RP}$ ) and ESI-Q-TOF MS analyses to profile scorpions' PMF. A phenetic correlation tree was provided based on venom PMF from each specie. Correlation was in agreement with the classical classification, showing that indeed venomic-based approaches may be used for taxonomical classifications.

Among the Buthidae scorpions, the genus Tityus is frequently studied by means of venomics [7,46,79-86]. Recently, a venomic study of Rhopalurus agamemnon New-World scorpion was reported [87]. R. agamemnon is a large scorpion $(\sim 11 \mathrm{~cm})$ found in the Brazilian savanna, known as "Cerrado". The authors performed a comprehensive characterization of $R$. agamemnon venom by bottom-up proteomics and enzymatic activity assays. The Centruroides is another New-World genus frequently subjected to venomic studies [88-93]. As observed in T. serrulatus venom by Pimenta et al. [75], it was reported individual variability in the Mexican scorpion Centruroides limpidus venom. Comparing the venom from male and female by PMF, and 2-DE followed by in-gel digestion and LC-ESI-Orbitrap MS analysis, the authors reported sexual dimorphism in C. limpidus venom [92]. Sexual dimorphism was also observed in C. hentzi venom [91].

Diaz et al. [89] studied the venom of Centruroides edwardsii by transcriptomics, proteomics, and bioassays. Venom proteomic analysis indicated the presence of a hyaluronidase, several cysteine-rich secretory proteins, metalloproteinases, and a peptidyl glycine $\alpha$-hydroxylating monooxygenase like-enzyme. They also identified peptides similar to the Kv neurotoxin margatoxin, a dominant toxin in the venom of its related scorpion C. margaritatus. They also identified Nav-modulating peptides similar to other scorpion species from Centruroides and Tityus genera.

Romero-Gutiérrez et al. [94] used transcriptomic and proteomic analyses to identify the components from the Serradigitus gertschi venom. They reported 119 annotated transcripts. The proteomic analysis revealed that 24 of the encoded peptides were indeed found in the venom. The study also revealed several unannotated transcript-derived peptides, demonstrating that there is still a number of scorpion venom components of unknown activity, reinforcing the idea that the functional characterization of the scorpion venoms is far from exhausted.

Although we focused on studies describing the New-World venomics, it is important to highlight that a number of venomic studies from Old-World scorpions have also been published [91,95-101].

For example, Xu et al. [100] used a proteomic strategy that combined multidimensional protein separation techniques (2-DE, SDS-PAGE, and RP-HPLC) with MS (ESI-Q-TOF MS and MALDI-TOF MS) to analyze the venom proteome of Mesobuthus martensii. The authors reported 227 peptides or proteins unambiguously identified, 115 of which were confirmed at the protein level from the crude venom, including 24 typical toxins, 7 atypical toxins, 12 venom enzymes, and 72 cellassociated proteins. Noteworthy, seven novel toxins belonging to typical toxins were also found in the M. martensii venom. 
Ma et al. [101] used a combination of expressed sequence tag (EST)-sequencing data from transcriptome analysis and MSbased proteomic methods on Heterometrus petersii venom. In total, 10 known and 12 unknown atypical toxin types, and 184 non-redundant venom toxins were identified. The diversity of the venome was demonstrated by the presence of at least 22 venom peptide families. Concurrently, numerous venom peptide families showed high homology with toxins from other animal species, indicating compositional convergence.

PTMs significantly change the physicochemical properties (e.g., structure, affinity, stability, interaction, etc.) of proteins, and so to animal protein toxins too. PTMs are frequently studied in cone snails', wasps' and snakes' venoms but somehow are overlooked in scorpions' and spiders' venomic papers. To the best of our knowledge, there is only one proteomic paper reporting that Tityus serrulatus venom proteins and peptides are subjected to PTMs (i.e., phosphorylation, $N$-linked glycosylation, and proteolysis) [82]. Despite the lack of such studies, PTMs do play an important role in the activity of arachnid venom proteins, as shown by Veiga et al. [102]. The enzymatic removal of potential N-glycosylated proteins in the venom of Loxosceles intermedia reduced the dermonecrotic and gelatinolytic activities of the crude venom. Thus, we urge our scientific community to pursue such task, employing enrichment steps for PTMs (phosphorylation, glycosylation, acetylation, etc.) on proteomic workflows, as illustrated in Figure 2, to shed more lights on the molecular complexity of scorpions' and spiders' venoms.

Finally, Table 1 summarizes key information related to the venomic studies cited in this review, including animal (spider or scorpion) genera, proteomic method and MS platform employed. Figure 3 represents such information as an interaction map. The nodes represent the terms reported in the table (arachnid genera, MS platform and proteomic strategy, also including the papers' corresponding authors). Node size represents the number of publications in which each term appeared. It is possible to observe in the Figure 3 that PTMs are indeed overlooked in venom proteome studies of scorpions and spiders.

Table 1. List of publications on spider and scorpion venomics cited in this review.

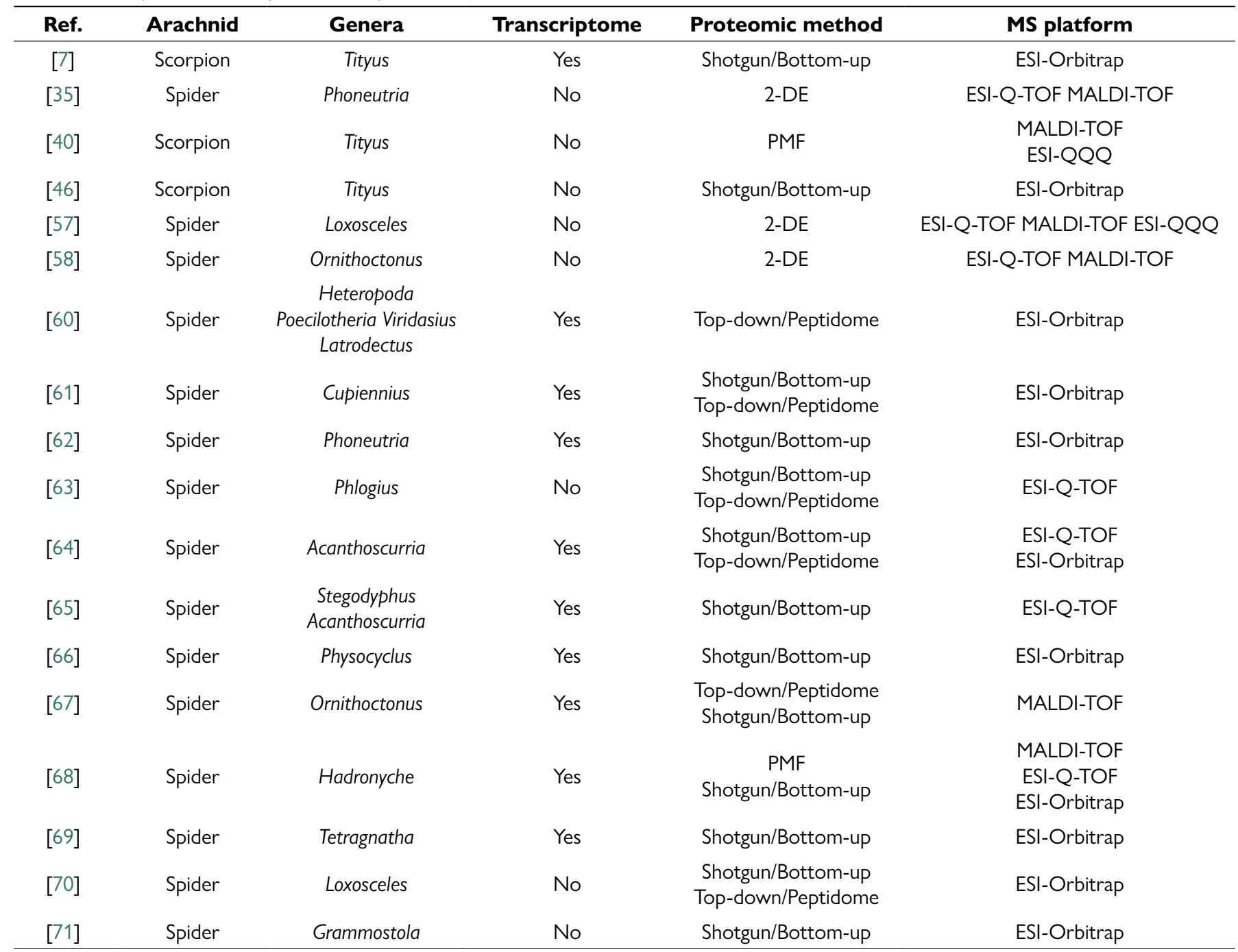


Table 1. Cont.

\begin{tabular}{|c|c|c|c|c|c|}
\hline Ref. & Arachnid & Genera & Transcriptome & Proteomic method & MS platform \\
\hline$[72]$ & Spider & Phoneutria & No & Shotgun/Bottom-up & $\begin{array}{l}\text { ESI-Orbitrap } \\
\text { ESI-Q-TOF }\end{array}$ \\
\hline$[74]$ & Scorpion & Tityus & No & PMF & $\begin{array}{l}\text { MALDI-TOF } \\
\text { ESI-IT }\end{array}$ \\
\hline$[77]$ & Scorpion & Rhopalurus & No & PMF & ESI-Orbitrap \\
\hline$[78]$ & Scorpion & $\begin{array}{l}\text { Tityus } \\
\text { Leiurus }\end{array}$ & No & PMF & ESI-Q-TOF \\
\hline [79] & Scorpion & Tityus & No & PMF & $\begin{array}{c}\text { ESI-IT } \\
\text { MALDI-TOF }\end{array}$ \\
\hline$[82]$ & Scorpion & Tityus & No & $\begin{array}{c}\text { Shotgun/Bottom-up } \\
\text { Top-down/Peptidome } \\
\text { PTMs }\end{array}$ & ESI-Orbitrap \\
\hline$[83]$ & Scorpion & Tityus & Yes & Shotgun/Bottom-up & ESI-Orbitrap \\
\hline$[84]$ & Scorpion & Tityus & No & PMF/Shotgun/Bottom-up & $\begin{array}{c}\text { ESI-IT } \\
\text { ESI-Orbitrap }\end{array}$ \\
\hline$[85]$ & Scorpion & Tityus & No & Top-down/Peptidome & ESI-IT-TOF \\
\hline$[86]$ & Scorpion & Tityus & No & PMF & ESI-IT \\
\hline$[87]$ & Scorpion & Rhopalurus & No & Shotgun/Bottom-up & ESI-Orbitrap \\
\hline [93] & Scorpion & Centruroides & Yes & PMF & $\begin{array}{c}\text { ESI-IT } \\
\text { ESI-Orbitrap }\end{array}$ \\
\hline$[95]$ & Scorpion & Buthus & No & $\begin{array}{l}\text { Shotgun/Bottom-up } \\
\text { Top-down/Peptidome }\end{array}$ & ESI-Orbitrap \\
\hline$[96]$ & Scorpion & Heterometrus & No & Shotgun/Bottom-up & MALDI-TOF \\
\hline [97] & Scorpion & Androctonus & No & PMF & MALDI-TOF \\
\hline [98] & Scorpion & Heterometrus & Yes & 2-DE & ESI-Q-TOF MALDI-TOF \\
\hline [99] & Scorpion & Mesobuthus & Yes & Shotgun/Bottom-up & ESI-Q-TOF \\
\hline$[100]$ & Scorpion & Mesobuthus & No & $\begin{array}{l}\text { PMF } \\
2-D E\end{array}$ & $\begin{array}{l}\text { MALDI-TOF } \\
\text { ESI-Q-TOF }\end{array}$ \\
\hline [101] & Scorpion & Heterometrus & Yes & Shotgun/Bottom-up & ESI-Q-TOF \\
\hline
\end{tabular}




\section{Conclusion}

We presented in this review historical landmarks of venomic studies on scorpion and spider venoms. It is fascinating to observe how venomics has evolved as MS instrumentation and proteomic methods have improved. From descriptive papers relying on PMF, we now find comprehensive venom characterization by means of omics methods. We prepared a table presenting the most important information from studies on venomics covered in this review article, including instrumentation and methods employed.

\section{Abbreviations}

1-DE: one-dimensional gel electrophoresis; 2-DE: twodimensional gel electrophoresis; CIEX: cation exchange chromatography; ESI: electrospray ionization; HPLC: highpressure liquid chromatography; IT: ion trap; LC: liquid chromatography; MALDI: matrix-assisted laser desorption/ ionization; MS/MS: tandem mass spectrometry; MS: mass spectrometry; NMR: nuclear magnetic resonance; PMF: peptide mass fingerprinting; Q: quadrupole; QQQ: triple quadrupole; RP: reverse-phase; TOF: time-of-flight.

\section{Availability of data and materials}

Not applicable.

\section{Funding}

The present study was supported by the following Brazilian agencies: FAPEMIG, CNPq and CAPES.

\section{Competing interests}

The authors declare that they have no competing interests.

\section{Authors' contributions}

FCM, EMS, LRR and LGBR wrote the manuscript. TVB defined the article's design and reviewed the manuscript. All authors read and approved the final manuscript.

\section{Ethics approval}

Not applicable.

\section{Consent for publication}

Not applicable.

\section{References}

1. Lourenço WR. Scorpion diversity and distribution: past and present patterns. In: Gopalakrishnakone P, Schwartz EF, Possani LD, de la Vega, editors. Scorpion Venoms. Netherlands, Dordrecht: Springer Link; 2013. p. 1-20. doi: 10.1007/978-94-007-6647-1_15-1.

2. Sharma PP, Fernández R, Esposito LA, González-Santillán E, Monod L. Phylogenomic resolution of scorpions reveals multilevel discordance with morphological phylogenetic signal. Proc Biol Sci. 2015 Apr 7;282(1804): 20142953. doi: 10.1098/rspb.2014.2953.
3. Lourenço WR, The evolution and distribution of noxious species of scorpions (Arachnida: Scorpiones), J Venom Anim Toxins incl Trop Dis. 2018 Jan 4;24:1. doi: 10.1186/s40409-017-0138-3.

4. Ward MJ, Ellsworth SA, Nystrom GS. A global accounting of medically significant scorpions: epidemiology, major toxins, and comparative resources in harmless counterparts. Toxicon. 2018 Sep 1;151:137-55. doi 10.1016/j.toxicon.2018.07.007.

5. Abroug F, Ouanes-Besbes L, Tilouche N, Elatrous S. Scorpion envenomation: state of the art. Intensive Care Med. 2020 Mar;46(3):40110. doi: 10.1007/s00134-020-05924-8.

6. Pucca MB, Amorim FG, Cerni FA, Bordon KCF, Cardoso IA, Anjolette FAP, Arantes EC. Influence of post-starvation extraction time and prey-specific diet in Tityus serrulatus scorpion venom composition and hyaluronidase activity. Toxicon. 2014 Nov;90:326-36. doi: 10.1016/j.toxicon.2014.08.064.

7. Fuzita FJ, Pinkse MWH, Patane JSL, Juliano MA, Verhaert PDEM, Lopes AR. Biochemical, transcriptomic and proteomic analyses of digestion in the scorpion Tityus serrulatus: insights into function and evolution of digestion in an ancient arthropod. PLoS One. 2015 Apr 15;10(4):e0123841. doi: 10.1371/journal.pone.0123841.

8. Sousa P, Arnedo MA, Harris DJ. Updated catalogue and taxonomic notes on the Old-World scorpion genus Buthus Leach, 1815 (Scorpiones, Buthidae). Zookeys. 2017 Jul 24;(686):15-84. doi: 10.3897/zookeys.686.12206.

9. Nentwig W. The prey of spiders. in: Nentwig W. Ecophysiology of Spiders. Springer, Berlin, Heidelberg: Springer Link; 1987. p. 249-63. doi:10.1007/978-3-642-71552-5.

10. Langenegger $\mathrm{N}$, Nentwig W, uhn-Nentwig L, Spider venom: components, modes of action, and novel strategies in transcriptomic and proteomic analyses, Toxins (Basel). 2019 Oct 22;11(10):611. doi: 10.3390/ toxins11100611.

11. Paiva ALB, Mudadu MA, Pereira EHT, Marri CA, Guerra-Duarte C, Diniz MRV. Transcriptome analysis of the spider Phoneutria pertyi venom glands reveals novel venom components for the genus Phoneutria. Toxicon. 2019 May;59-69. doi: 10.1016/j.toxicon.2019.03.014.

12. Escoubas P, Diochot S, Corzo G, Structure and pharmacology of spider venom neurotoxins. Biochimie. 2000 Sep-Oct;82(9-10):893-907. doi: 10.1016/s0300-9084(00)01166-4.

13. Cardoso JLC, França FOS, Wen FH, Málaque CMS, Haddad Jr V. Venomous animals in Brazil: biology, clinic and therapeutics of envenomations. Rev Inst Med Trop S Paulo. 2003 Dec;45(6):338. doi:10.1590/S003646652003000600009.

14. Chaves-Moreira D, Senff-Ribeiro A, Wille ACM, Gremski LH, Chaim OM, Veiga SS. Highlights in the knowledge of brown spider toxins. J Venom Anim Toxins incl Trop Dis. 2017 Feb 8;23:6. doi: 10.1186/s40409-017-0097-8.

15. Chaves-Moreira D, Matsubara FH, Schemczssen-Graeff Z, De Bona E, Heidemann VR, Guerra-Duarte C, Gremski LH, Chávez-Olórtegui C, Senff-Ribeiro A, Chaim OM, Arni RK, Veiga SS. Brown spider (Loxosceles) venom toxins as potential biotools for the development of novel therapeutics. Toxins (Basel). 2019 Jun 19;11(6):355. doi: 10.3390/ toxins11060355.

16. da Silva PH, da Silveira RB, Appel MH, Mangili OC, Gremski W, Veiga SS. Brown spiders and loxoscelism. Toxicon. 2004 Dec 1;44(7):693-709. doi:10.1016/j.toxicon.2004.07.012.

17. Yan $A$, Wang $X$. Recent advances in research on widow spider venoms and toxins. Toxins (Basel). 2015 Nov 27;7(12):5055-67. doi: 10.3390/ toxins7124862.

18. Isbister GK, Fan HW. Spider bite. Lancet. 2011 Dec 10;378(9808):2039-47. doi: 10.1016/S0140-6736(10)62230-1.

19. Peigneur S, de Lima ME, Tytgat J. Phoneutria nigriventer venom: a pharmacological treasure. Toxicon. 2018 Sep 1:96-110. doi: 10.1016/j. toxicon.2018.07.008.

20. Lauria PSS, Villarreal CF, Casais-e-Silva LL. Pain modulatory properties of Phoneutria nigriventer crude venom and derived peptides: a doubleedged sword. Toxicon. 2020 Oct 15;185:120-8. doi: 10.1016/j. toxicon.2020.07.005.

21. Rezende Júnior L, Cordeiro MN, Oliveira EB, Diniz CR. Isolation of neurotoxic peptides from the venom of the 'armed' spider Phoneutria nigriventer. Toxicon. 1991;1225-33. doi:10.1016/0041-0101(91)90195-w. 
22. Bucaretchi F, Mello SM, Vieira RJ, Mamoni RL, Blotta MHSL, Antunes E, Hyslop S. Systemic envenomation caused by the wandering spider Phoneutria nigriventer, with quantification of circulating venom. Clin Toxicol (Phila). 2008 Nov;46(9):885-9. doi: 10.1080/15563650802258524.

23. Herzig V, Sunagar K, Wilson DTR, Pineda SS, Israel MR, Dutertre S, McFarland BS, Undheim EAB, Hodgson W, Alewood PF, Lewis RJ, Bosmans F, Vetter I, King GF, Fry BG. Australian funnel-web spiders evolved human-lethal $\delta$-hexatoxins for defense against vertebrate predators. Proc Natl Acad Sci U S A. 2020 Oct 6;117(40):24920-8. doi: 10.1073/ pnas. 2004516117.

24. Verano-Braga T, Rocha-Resende C, Silva DM, lanzer D, MartinEauclaire MF, Bougis PE, de Lima ME, Santos RAS, Pimenta AMC. Tityus serrulatus hypotensins: a new family of peptides from scorpion venom. Biochem Biophys Res Commun. 2008 Jul 4;371(3):515-20. doi: 10.1016/j. bbrc.2008.04.104.

25. Verano-Braga T, Figueiredo-Rezende F, Melo MN, Lautner RQ, Gomes ERM, Mata-Machado LT, Murari A, Rocha-Resende C, de Lima ME, Guatimosim S, Santos RAS, Pimenta AMC. Structure-function studies of Tityus serrulatus hypotensin-I (TsHpt-I): a new agonist of $B_{2}$ kinin receptor. Toxicon. 2010 Dec 15;56(7):1162-71. doi: 10.1016/j.toxicon.2010.04.006.

26. Machado RJA, Leônidas Junior GM, Monteiro NKV, Silva-Júnior AA, Portaro FCV, Barbosa EG, Braga VA, Fernandes-Pedrosa MF. Homology modeling, vasorelaxant and bradykinin-potentiating activities of a novel hypotensin found in the scorpion venom from Tityus stigmurus. Toxicon. 2015 Jul;101:11-8. doi: 10.1016/j.toxicon.2015.04.003.

27. Goméz-Mendoza DP, Lemos RP, Jesus ICG, Gorshkov V, McKinnie SMK, Vederas JC, Kjeldsen F, Guatimosim S, Santos RA, Pimenta AMC, Verano-Braga T. Moving pieces in a cellular puzzle: a cryptic peptide from the scorpion toxin Ts14 activates AKT and ERK signaling and decreases cardiac myocyte contractility via dephosphorylation of phospholamban., J Proteome Res. 2020 Aug 7;19(8):3467-77. doi: 10.1021/ acs.jproteome.0c00290.

28. Nunes KP, Costa-Gonçalves A, Lanza LF, Cortes SF, Cordeiro MN, Richardson M, Pimenta AMC, Webb RC, Leite R, De Lima ME. T×2-6 toxin of the Phoneutria nigriventer spider potentiates rat erectile function. Toxicon. 2008 Jun 1;51(7):1197-206. doi: 10.1016/j.toxicon.2008.02.010.

29. Silva CN, Nunes KP, Torres FS, Cassoli JS, Santos DM, Almeida FM, Matavel A, Cruz JS, Santos-Miranda A, Nunes ADC, Castro CH, Machado de Ávila RA, Chávez-Olórtegui C, Láuar SS, Felicori F, Resende JM, Camargos ERS, Borges MH, Cordeiro MN, Peigneur S, Tytgat J, de Lima ME. PnPP-19, a synthetic and nontoxic peptide designed from a Phoneutria nigriventer toxin, potentiates erectile function via NO/cGMP., J Urol. 2015 Nov;194(5):1481-90. doi: 10.1016/j.juro.2015.06.081.

30. Song YM, Tang XX, Chen XG, Gao BB, Gao E, Bai L, Lv XR. Effects of scorpion venom bioactive polypolypeptides on platelet aggregation and thrombosis and plasma 6-keto-PG $F_{1 a}$ and $T \mathrm{~TB}_{2}$ in rabbits and rats. Toxicon. 2005 Aug;46(2):230-5. doi: 10.1016/j.toxicon.2005.04.012.

31. Zheng M, Yan X, Bu F, Zhang F, Li Z, Cui J, Liu J, Dong M. Structural characterization of: Mesobuthus martensii Karsch peptides and antiinflammatory potency evaluation in human vascular endothelial cells. RSC Adv. 2019 Jun 20;9(34):19365-74. doi: 10.1039/C9RA01609K.

32. Reis PVM, Boff D, Verly RM, Melo-Braga MN, Cortés ME, Santos DM, Pimenta AMC, Amaral FA, Resende JM, de Lima ME. LyeTxl-b, a synthetic peptide derived from Lycosa erythrognatha spider venom, shows potent antibiotic activity in vitro and in vivo. Front Microbiol. 2018 Apr 6;9:667. doi: 10.3389/fmicb.2018.00667.

33. Harrison PL, Abdel-Rahman MA, Miller K, Strong PN. Antimicrobial peptides from scorpion venoms. Toxicon. 2014 Sep;88:115-37. doi: 10.1016/j.toxicon.2014.06.006.

34. Windley MJ, Herzig V, Dziemborowicz SA, Hardy MC, King GF, Nicholson GM. Spider-venom peptides as bioinsecticides. Toxins (Basel). 2012 Mar;4(3):191-227. doi: 10.3390/toxins4030191.

35. Richardson M, Pimenta AMC, Bemquerer MP, Santoro MM, Beirao PSL, Lima ME, Figueiredo SG, Bloch Jr C, Vasconcelos EAR, Campos FAP, Gomes PC, Cordeiro MN. Comparison of the partial proteomes of the venoms of brazilian spiders of the genus Phoneutria. Comp Biochem Physiol C Toxicol Pharmacol. 2006 Mar-Apr;142(3-4):173-87. doi: 10.1016/j. cbpc.2005.09.010.
36. Saez NJ, Senff S, Jensen JE, Er SY, Herzig V, Rash LD, King GF. Spidervenom peptides as therapeutics. Toxins (Basel). 2010 Dec;2(12):2851-71. doi: $10.3390 /$ toxins 2122851 .

37. Rochat C, Rochat H, Miranda F, Lissitzky S. Purification and some properties of the neurotoxins of Androctonus australis Hector. Biochemistry. 1967 Feb;6(2):578-85. doi: 10.1021/bi00854a028.

38. Fuzita FJ, Pinkse MWH, Patane JSL, Verhaert PDEM, Lopes AR. High throughput techniques to reveal the molecular physiology and evolution of digestion in spiders. BMC Genomics. 2016 Sep 7;17(1):716. doi: 10.1186/ s12864-016-3048-9.

39. Wilson D, Daly NL. Venomics: a mini-review. High Throughput. 2018 Jul 23;7(3):19. doi: 10.3390/ht7030019.

40. Pimenta AMC, Stcklin R, Favreau P, Bougis PE, Martin-Eauclaire MF. Moving pieces in a proteomic puzzle: mass fingerprinting of toxic fractions from the venom of Tityus serrulatus (Scorpiones, Buthidae). Rapid Commun Mass Spectrom. 2001 Aug 10;15(17):1562-72. doi: 10.1002/rcm.415.

41. Duffield PH, Duffield AM, Carroll PR, Morgans D. Analysis of the venom of the sydney funnel-web spider, Atrax robustus using gas chromatography mass spectrometry. Biomed Mass Spectrom. 1979 Mar;6(3):105-8.doi: 10.1002/bms.1200060305.

42. Griffiths J. A brief history of mass spectrometry. Anal Chem. 2008 Aug 1;80(15):5678-83. doi: 10.1021/ac8013065.

43. Yamashita M, Fenn JB. Electrospray ion source. Another variation on the free-jet theme. J Phys Chem. 1984 Sep 1;88(20):4451-9. doi: 10.1021/ j150664a002.

44. Karas M, Bachmann D, Hillenkamp F. Influence of the wavelength in high-Irradiance ultraviolet laser desorption mass spectrometry of organic molecules. Anal Chem. 1985 Dec 1;57(14):2935-9. doi: 10.1021/ ac00291a042.

45. [Muth T, Hartkopf F, Vaudel M, Renard BY. A potential golden age to come-current tools, recent use cases, and future avenues for De Novo sequencing in proteomics. Proteomics. 2018 Sep;18(18):e1700150. doi: 10.1002/pmic.201700150.

46. Gorshkov V, Hotta SYK, Verano-Braga T, Kjeldsen F. Peptide de novo sequencing of mixture tandem mass spectra. Proteomics. 2016 Sep;16(18):2470-9. doi: 10.1002/pmic.201500549.

47. Melo-Braga MN, Ibáñez-Vea M, Larsen MR, Kulej K. Comprehensive protocol to simultaneously study protein phosphorylation, acetylation, and N-linked sialylated glycosylation. Methods Mol Biol. 2014;1259:275-92. doi: 10.1007/978-1-4939-2550-6_21.

48. Melo-Braga MN, Ibáñez-Vea M, Kulej K, Larsen MR. Comprehensive protocol to simultaneously study protein phosphorylation, acetylation, and $\mathrm{N}$-linked sialylated glycosylation. Methods Mol Biol. 2021 Jan 10;2261:5572. doi: 10.1007/978-1-0716-1186-9_5.

49. He QY, He QZ, Deng XC, Yao L, Meng E, Liu ZH, Liang SP. ATDB: a uni-database platform for animal toxins. Nucleic Acids Res. 2008) Jan;26(Suppl_1):D293-7. doi: 10.1093/nar/gkm832.

50. Jungo F, Bougueleret L, Xenarios I, Poux S. The UniProtKB/Swiss-Prot Tox-Prot program: a central hub of integrated venom protein data. Toxicon. 2012 Sep 15;60(4):551-7. doi: 10.1016/j.toxicon.2012.03.010.

51. Jungo F, Estreicher A, Bairoch A, Bougueleret L, Xenarios I. Animal toxins: how is complexity represented in databases?. Toxins (Basel). 2010 Feb;2(2):262-82. doi: 10.3390/toxins2020261.

52. Herzig V, Wood DLA, Newell F, Chaumeil PA, Kaas Q, Binford GJ, Nicholson GM, Gorse D, King GF. ArachnoServer 2.0, an updated online resource for spider toxin sequences and structures. Nucleic Acids Res. 2011 Jan;39(Suppl_1):D653-7. doi: 10.1093/nar/gkq1058.

53. Gacesa R, Barlow DJ, Long PF. Machine learning can differentiate venom toxins from other proteins having non-toxic physiological functions. Peer] Computer Sci 2. 2016 Oct 10:e90. doi: 10.7717/peerj-cs.90.

54. Srinivasan KN, Gopalakrishnakone P, Tan PT, Chew KC, Cheng B, Kini RM, Koh JLY, Seah SH, Brusic V. SCORPION, a molecular database of scorpion toxins. Toxicon. 2002 Jan;40(1)23-31. doi: 10.1016/s00410101(01)00182-9.

55. Tan PTJ, Veeramani A, Srinivasan KN, Ranganathan S, Brusic V. SCORPION2: a database for structure-function analysis of scorpion toxins. Toxicon. 2006 Mar;47(3):356-63. doi: 10.1016/j.toxicon.2005.12.001. 
56. King GF, Gentz MC, Escoubas P, Nicholson GM. A rational nomenclature for naming peptide toxins from spiders and other venomous animals. Toxicon. 2008 Aug 1;52(2):264-76. doi: 10.1016/j.toxicon.2008.05.020.

57. Machado LF, Laugesen S, Botelho ED, Ricart CAO, Fontes W, Barbaro KC, Roepstorff P, Sousa MV. Proteome analysis of brown spider venom: identification of loxnecrogin isoforms in Loxosceles gaucho venom. Proteomics. 2005 May;5(8):2167-76. doi: 10.1002/pmic.200401096.

58. Yuan C, Jin Q, Tang X, Hu W, Cao R, Yang S, Xiong J, Xie C, Xie J, Liang $S$. Proteomic and peptidomic characterization of the venom from the chinese bird spider, Ornithoctonus huwena Wang. J Proteome Res. 2007 Jul;6(7):2792-801. doi: 10.1021/pr0700192.

59. Hu Q, Noll RJ, Li H, Makarov A, Hardman M, Graham Cooks R. The Orbitrap: a new mass spectrometer.J Mass Spectrom. 2005 Apr;40(4):430 43. doi: $10.1002 / j m s .856$.

60. Oldrati $\mathrm{V}$, Koua D, Allard PM, Hulo N, Arrell M, Nentwig W, Lisacek F, Wolfender JL, Kuhn-Nentwig L, Stöcklin R. Peptidomic and transcriptomic profiling of four distinct spider venoms. PLoS One. 2017 Mar 17;12(3):e0172966. doi: 10.1371/journal.pone.0172966.

61. Kuhn-Nentwig L, Langenegger N, Heller M, Koua D, Nentwig W. The dual prey-inactivation strategy of spiders-in-depth venomic analysis of Cupiennius salei. Toxins (Basel). 2019 Mar 19;11(3):167. doi: 10.3390/ toxins11030167.

62. Diniz MRV, Paiva ALB, Guerra-Duarte C, Nishiyama Jr MY, Mudadu MA, de Oliveira U, Borges MH, Yates JR, Junqueira-de-Azevedo IL. An overview of Phoneutria nigriventer spider venom using combined transcriptomic and proteomic approaches. PLoS One. 2018 Aug 1;13(8):e0200628. doi: 10.1371/journal.pone.0200628.

63. Santana RC, Perez D, Dobson J, Panagides N, Raven RJ, Nouwens A, Jones A, King GF, Fry BG. Venom profiling of a population of the theraphosid spider Phlogius crassipes reveals continuous ontogenetic changes from juveniles through adulthood. Toxins (Basel). 2017 Mar 25;9(4):116. doi: 10.3390/toxins 9040116.

64. Câmara GA, Nishiyama-Jr MY, Kitano ES, Oliveira UC, da Silva Jr PI, Junqueira-de-Azevedo IL, Tashima AK. A multiomics approach unravels new toxins with possible in silico antimicrobial, antiviral, and antitumoral activities in the venom of Acanthoscurria rondoniae. Front Pharmacol. 2020 Jul 17;11:1075. doi: 10.3389/fphar.2020.01075.

65. Sanggaard KW, Bechsgaard JS, Fang X, Duan J, Dyrlund TF, Gupta V, Jiang $X$, Cheng L, Fan D, Feng $Y$, Han L, Huang Z, Wu Z, Liao L, Settepani V, Thøgersen IB, Vanthournout B, Wang T, Zhu Y, Funch P, Enghild JJ, Schauser L, Andersen SU, Villesen P, Schierup MH, Bilde T, Wang J. Spider genomes provide insight into composition and evolution of venom and silk. Nat Commun. 2014 May 6;5:3765. doi: 10.1038/ncomms4765.

66. Zobel-Thropp PA, Mullins J, Kristensen C, Kronmiller BA, David CL, Breci LA, Binford GJ. Not so dangerous after all? Venom composition and potency of the pholcid (daddy long-leg) spider Physocyclus mexicanus. Front Ecol Evol. 2019 Jul;7:256. doi: 10.3389/fevo.2019.00256.

67. Tang X, Zhang Y, Hu W, Xu D, Tao H, Yang X, Li Y, Jiang L, Liang S. Molecular diversification of peptide toxins from the tarantula Haplopelma hainanum (Ornithoctonus hainana) venom based on transcriptomic, peptidomic, and genomic analyses. J Proteome Res. 2010 May 7;9(5):2550-64. doi: 10.1021/pr1000016.

68. Pineda SS, Chin YKY, Undheim EAB, Senff S, Mobli M, Dauly C, Escoubas P, Nicholson GM, Kaas Q, Guo S, Herzig V, Mattick JS, King GF. Structural venomics reveals evolution of a complex venom by duplication and diversification of an ancient peptide-encoding gene. Proc Natl Acad Sci U S A. 2020 May 26;117(21):11399-408. doi: 10.1073/pnas.1914536117.

69. Zobel-Thropp PA, Bulger EA, Cordes MHJ, Binford GJ, Gillespie RG, Brewer MS. Sexually dimorphic venom proteins in long-jawed orb-weaving spiders (Tetragnatha) comprise novel gene families. PeerJ. 2018 Jun 1;6: e4691. doi: 10.7717/peerj.4691.

70. Trevisan-Silva D, Bednaski AV, Fischer JSG, Veiga SS, Bandeira N, Guthals A, Marchini FK, Leprevost FV, Barbosa VC, Senff-Ribeiro A, Carvalho PC. A multi-protease, multi-dissociation, bottom-up-to-top-down proteomic view of the Loxosceles intermedia venom. Sci Data. 2017 Jul 11;4:170090. doi: 10.1038/sdata.2017.90.
71. Borges MH, Figueiredo SG, Leprevost FV, De Lima ME, Cordeiro MN, Diniz MRV, Moresco J, Carvalho PC, Yates JR. Venomous extract protein profile of brazilian tarantula Grammostola iheringi: searching for potential biotechnological applications. J Proteomics. 2016 Mar 16;136:35-47. doi:10.1016/j.jprot.2016.01.013.

72. Liberato T, Troncone LRP, Yamashiro ET, Serrano SMT, Zelanis A. Highresolution proteomic profiling of spider venom: expanding the toxin diversity of Phoneutria nigriventer venom. Amino Acids. 2016 Mar;48(3):901-6. doi: 10.1007/s00726-015-2151-6.

73. Zobel-Thropp PA, Correa SM, Garb JE, Binford GJ. Spit and venom from scytodes spiders: a diverse and distinct cocktail. J Proteome Res. $2014 \mathrm{Feb}$ 7;13(2):817-35. doi: 10.1021/pr400875s.

74. Batista CVF, Del Pozo L, Zamudio FZ, Contreras S, Becerril B, Wanke E, Possani LD. Proteomics of the venom from the amazonian scorpion Tityus cambridgei and the role of prolines on mass spectrometry analysis of toxins. J Chromatogr B Analyt Technol Biomed Life Sci. 2004 Apr 15;803(1):55-66. doi: 10.1016/j.jchromb.2003.09.002.

75. Pimenta AMC, Almeida FDM, de Lima ME, Martin-Eauclaire MF, Bougis PE. Individual variability in Tityus serrulatus (Scorpiones, Buthidae) venom elicited by matrix-assisted laser desorption/ionization time-of-flight mass spectrometry. Rapid Commun Mass Spectrom. 2003;17(5):413-8. doi: 10.1002/rcm.934.

76. Rodríguez-Ravelo R, Coronas FIV, Zamudio FZ, González-Morales L, López GE, Urquiola AR, Possani LD. The cuban scorpion Rhopalurus junceus (Scorpiones, Buthidae): component variations in venom samples collected in different geographical areas. J Venom Anim Toxins incl Trop Dis. 2013 May 20;19(1):13. doi: 10.1186/1678-9199-19-13.

77. Rodríguez-Ravelo R, Batista CVF, Coronas FIV, Zamudio FZ, HernándezOrihuela L, Espinosa-López G, Ruiz-Urquiola A, Possani LD. Comparative proteomic analysis of male and female venoms from the cuban scorpion Rhopalurus junceus. Toxicon. 2015 Dec 1;107(Pt B):327-34. doi: 10.1016/j. toxicon.2015.06.026.

78. Nascimento DG, Rates B, Santos DM, Verano-Braga T, Barbosa-Silva A, Dutra AAA, Biondi I, Martin-Eauclaire MF, De Lima ME, Pimenta AMC. Moving pieces in a taxonomic puzzle: venom 2D-LC/MS and data clustering analyses to infer phylogenetic relationships in some scorpions from the Buthidae family (Scorpiones). Toxicon. 2006 May;47(6):628-39. doi: 10.1016/j. toxicon.2006.01.015.

79. Batista CVF, D'Suze G, Gómez-Lagunas F, Zamudio FZ, Encarnación S, Sevcik C, Possani LD. Proteomic analysis of Tityus discrepans scorpion venom and amino acid sequence of novel toxins. Proteomics. 2006 Jun;6(12):3718-27. doi: 10.1002/pmic. 200500525.

80. Batista CVF, Román-González SA, Salas-Castillo SP, Zamudio FZ, GómezLagunas F, Possani LD. Proteomic analysis of the venom from the scorpion Tityus stigmurus: biochemical and physiological comparison with other Tityus species. Comp Biochem Physiol C Toxicol Pharmacol. 2007 JulAug;146(1-2):147-57. doi: 10.1016/j.cbpc.2006.12.004.

81. Amorim FG, Longhim HT, Cologna CT, Degueldre M, De Pauw E, Quinton $\mathrm{L}$, Arantes EC. Proteome of fraction from Tityus serrulatus venom reveals new enzymes and toxins. J Venom Anim Toxins incl Trop Dis. 2019 Apr 18;25:e148218. doi: 10.1590/1678-9199-JVATITD-1482-18.

82. Verano-Braga T, Dutra AAA, León IR, Melo-Braga MN, Roepstorff P, Pimenta AMC, Kjeldsen F. Moving pieces in a venomic puzzle: unveiling post-translationally modified toxins from Tityus serrulatus. J Proteome Res. 2013 Jul 5;12(7):3460-70. doi: 10.1021/pr4003068.

83. de Oliveira UC, Nishiyama Jr MY, dos Santos MBV, Santos-da-Silva AP, Chalkidis HM, Souza-Imberg A, Candido DM, Yamanouye N, Dorce VAC, Junqueira-de-Azevedo ILM. Proteomic endorsed transcriptomic profiles of venom glands from Tityus obscurus and T. serrulatus scorpions. PLoS One. 2018 Mar 21;13(3):e0193739. doi: 10.1371/journal.pone.0193739.

84. Batista CVF, Martins JG, Restano-Cassulini R, Coronas FIV, Zamudio FZ, Procópio R, Possani LD. Venom characterization of the amazonian scorpion Tityus metuendus. Toxicon. 2018 Mar 1;51-8. doi: 10.1016/j. toxicon.2018.01.006.

85. Dias NB, de Souza BM, Cocchi FK, Chalkidis HM, Dorce VAC, Palma MS. Profiling the short, linear, non-disulfide bond-containing peptidome from the venom of the scorpion Tityus obscurus. J Proteomics. 2018 Jan 6;170:70-9. doi: 10.1016/j.jprot.2017.09.006. 
86. Barona J, Batista CVF, Zamudio FZ, Gomez-Lagunas F, Wanke E, Otero $R$, Possani LD. Proteomic analysis of the venom and characterization of toxins specific for $\mathrm{Na}^{+}$- and $\mathrm{K}^{+}$-channels from the colombian scorpion Tityus pachyurus. Biochim Biophys Acta. 2006 Jan;1764(1):76-84. doi: 10.1016/j.bbapap.2005.08.010.

87. Magalhães ACM, de Santana CJC, Melani RD, Domont GB, Castro MS, Fontes W, Roepstorff P, Pires Júnior OR. Exploring the biological activities and proteome of brazilian scorpion Rhopalurus agamemnon venom. J Proteomics. 2021 Apr 15;237:104119. doi: 10.1016/j.jprot.2021.104119.

88. Valdez-Velázquez LL, Cid-Uribe J, Romero-Gutierrez MT, OlamendiPortugal T, Jimenez-Vargas JM, Possani LD. Transcriptomic and proteomic analyses of the venom and venom glands of Centruroides hirsutipalpus, a dangerous scorpion from Mexico. Toxicon. 2020 May;179:21-32. doi: 10.1016/j.toxicon.2020.02.021.

89. Díaz C, Rivera J, Lomonte B, Bonilla F, Diego-García E, Camacho E, Tytgat J, Sasa M. Venom characterization of the bark scorpion Centruroides edwardsii (Gervais 1843): composition, biochemical activities and in vivo toxicity for potential prey. Toxicon. 2019 Dec 5;171:7-19. doi: 10.1016/j. toxicon.2019.09.021.

90. Cid-Uribe JI, Meneses EP, Batista CVF, Ortiz E, Possani LD. Dissecting toxicity: the venom gland transcriptome and the venom proteome of the highly venomous scorpion Centruroides limpidus (Karsch, 1879). Toxins (Basel). 2019 Apr 30;11(5):247. doi: 10.3390/toxins11050247.

91. Ward MJ, Ellsworth SA, Rokyta DR. Venom-gland transcriptomics and venom proteomics of the Hentz striped scorpion (Centruroides hentzi; Buthidae) reveal high toxin diversity in a harmless member of a lethal family. Toxicon. 2018 Feb;142:14-29. doi: 10.1016/j.toxicon.2017.12.042.

92. Cid Uribe JI, Jiménez Vargas JM, Ferreira Batista CV, Zamudio Zuñiga F, Possani LD. Comparative proteomic analysis of female and male venoms from the mexican scorpion Centruroides limpidus: novel components found. Toxicon. 2017 Jan;125:91-8. doi: 10.1016/j.toxicon.2016.11.256.

93. Valdez-Velázquez LL, Quintero-Hernández V, Romero-Gutiérrez MT, Coronas FIV, Possani LD. Mass fingerprinting of the venom and transcriptome of venom gland of scorpion Centruroides tecomanus. PLoS One. 2013 Jun 20;8(6):e66486. doi: 10.1371/journal.pone.0066486.
94. Romero-Gutiérrez MT, Santibáñez-López CE, Jiménez-Vargas JM, Batista CVF, Ortiz E, Possani LD. Transcriptomic and proteomic analyses reveal the diversity of venom components from the vaejovid scorpion Serradigitus gertschi. Toxins (Basel). 2018) Sep 5;10(9):359. doi: 10.3390/toxins10090359.

95. [Daoudi K, Malosse C, Lafnoune A, Darkaoui B, Chakir S, Sabatier JM, Chamot-Rooke J, Cadi R, Oukkache N. Mass spectrometry-based topdown and bottom-up approaches for proteomic analysis of the moroccan Buthus occitanus scorpion venom. FEBS Open Bio. 2021 Jul;11(7):1867-92. doi: 10.1002/2211-5463.13143.

96. Bringans S, Eriksen S, Kendrick T, Gopalakrishnakone P, Livk A, Lock R, Lipscombe R. Proteomic analysis of the venom of Heterometrus longimanus (asian black scorpion). Proteomics. 2008 Mar;8(5):1081-96. doi: 10.1002/ pmic. 200700948.

97. Oukkache N, Rosso JP, Alami M, Ghalim N, Saïle R, Hassar M, Bougis PE, Martin-Eauclaire MF. New analysis of the toxic compounds from the Androctonus mauretanicus mauretanicus scorpion venom. Toxicon. 2008 Apr;51(5):835-52. doi: 10.1016/j.toxicon.2007.12.012.

98. Incamnoi P, Patramanon R, Thammasirirak S, Chaveerach A, Uawonggul N, Sukprasert S, Rungsa P, Daduang J, Daduang S. Heteromtoxin ( $\mathrm{HmTx}$ ), a novel heterodimeric phospholipase $A_{2}$ from Heterometrus laoticus scorpion venom. Toxicon. 2013 Jan;61:62-71. doi: 10.1016/j.toxicon.2012.10.012.

99. Gao S, Liang H, Shou Z, Yao Y, Lv Y, Shang J, Lu W, Jia C, Liu Q, Zhang H, Xiao L. De novo transcriptomic and proteomic analysis and potential toxin screening of Mesobuthus martensii samples from four different provinces. J Ethnopharmacol. 2021 Jan 30;265:113268. doi: 10.1016/j.jep.2020.113268.

100. Xu X, Duan Z, Di Z, He Y, Li J, Li Z, Xie C, Zeng X, Cao Z, Wu Y, Liang S, Li W. Proteomic analysis of the venom from the scorpion Mesobuthus martensii. J Proteomics. 2014 Jun 25;106:162-80. doi: 10.1016/j.jprot.2014.04.032.

101. Ma Y, Zhao Y, Zhao R, Zhang W, He Y, Wu Y, Cao Z, Guo L, Li W. Molecular diversity of toxic components from the scorpion Heterometrus petersii venom revealed by proteomic and transcriptome analysis. Proteomics. 2010 Jul;10(13):2471-85. doi: 10.1002/pmic. 200900763.

102. Veiga SS, Gremski W, dos Santos VLP, Feitosa L, Mangili OC, Nader HB, Dietrich CP, Brentani RR. Oligosaccharide residues of Loxosceles intermedia (brown spider) venom proteins: dependence on glycosylation for dermonecrotic activity. Toxicon. 1999 Apr;37(4):587-607. doi: 10.1016/ s0041-0101(98)00198-6. 